\title{
克隆植物乌菱对底泥磷含量及植株密度的 表型可塑性响应
}

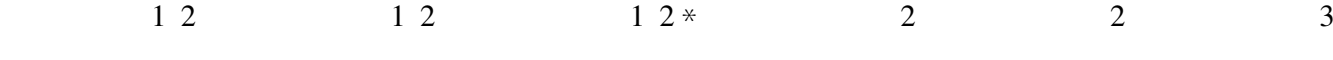 \\ (1 污染控制与资源化研究国家重点实验室, 南京大学生命科学学院, 南京 210093) \\ (2 南京大学湿地生态研究所, 南京 210093) (3 中国科学院华南植物园 ,广州 510650)
}

\begin{abstract}
摘 要 植物, 尤其是克隆植物, 能够通过表型变化来缓解外界压力, 提高对环境的适应能力。该文研究了水生克 隆植物乌菱 (Trapa bicornis) 对底泥磷含量 (Sediment phosphorus concentration, SP)、植株密度 (Plant density, PD) 及两者 间交互作用的可塑性响应, 探讨可塑性是否能促进其在富营养化环境中的生长。结果显示, 底泥磷含量对乌菱的 主菱盘叶数、同化根比根长、吸收根比根长以及叶、茎、同化根、吸收根与植株总磷含量等都有显著影响 $(p<0.05)$, 而植株密度对乌菱各生长及生理生态参数均无显著作用 $(p>0.05)$; $\mathrm{SP}$ 与 $\mathrm{PD}$ 的交互作用弱化了底泥磷含量对乌 菱的效应。底泥磷含量和植株密度甚至改变了同化根、吸收根、茎、叶与总生物量之间的异速生长关系。研究结果 表明 :乌菱的表型可塑性变化主要受底泥磷含量的影响 乌菱通过器官生物量分配、形态结构及生理生态特征的调 整来响应底泥磷含量的变化;同时, 高的植株密度也可以提高其在富营养化生境下的生态适应性。
\end{abstract}

关键词 表型可塑性 底泥磷含量 植株密度 乌菱 克隆植物 生态适应性

\section{PHENOTYPIC PLASTICITY OF THE CLONAL PLANT TRAPA BICORNIS IN RE- SPONSE TO SEDIMENT PHOSPHORUS CONCENTRATION AND PLANT DENSITY}

\author{
CAI Ying ${ }^{1}{ }^{2}$, GUAN Bao-Hua $^{12}$, AN Shu-Qing $^{12 *}{ }^{2 *}$ SHEN Rui-Ling ${ }^{2}$, JIANG Jin-Hui $^{2}$, and DONG Lei ${ }^{3}$ \\ ${ }^{I}$ The State Key Laboratory of Pollution Control and Resource Reuse , School of Life Science , Nanjing University , Nanjing 210093 , China , ${ }^{2}$ Institute \\ of Wetland Ecology , Nanjing University , Nanjing 210093 , China , and ${ }^{3}$ South China Botany Garden , Chinese Academy of Sciences , Guangzhou \\ 510650 , China
}

\begin{abstract}
Aims Trapa bicornis is a clonal floating macrophyte that dominates several lakes in China. Due to eutrophication, the distribution of $T$. bicornis is shrinking, and $T$. bicornis has disappeared in some lakes. Our objectives were to investigate the effects of sediment phosphorus concentration (SP), plant density (PD) and their interaction on the plasticity of $T$. bicornis and examine whether plasticity could promote ecological adaptation in eutrophic environments.
\end{abstract}

Methods In a controlled factorial experiment, we grew artificial populations of $T$. bicornis in low , medium and high PD (4,8 and 12 individuals per container, respectively) under low , medium and high SP. We harvested all plants after six weeks and measured the dry mass for each plant part.

Important findings SP significantly affected leaf , stem, green root, anchoring root and total plant phosphorus concentrations as well as number of main rosettes of trullate floating leaves, special green root length and special anchoring root length of $T$. bicornis, but PD did not significantly affect any growth or ecophysiological traits. With increasing SP , plant phosphorus concentration increased. Number of main rosettes of trullate floating leaves of $T$. bicornis was the largest at low SP and low PD, leaf mass ratio at medium SP and high PD , special green root length at high SP and medium PD , and special anchoring root length at high SP and high PD. SP , PD and their interaction altered some of the allometric relationships between leaf, stem, green root, anchoring root and total biomass. Morphological and ecophysiological traits mostly affected by SP and high PD may increase the ecological adaptability of $T$. bicornis under eutrophic conditions caused mainly by phosphorus.

Key words phenotypic plasticity, sediment P concentration, plant density , Trapa bicornis, clonal plants , ecological adaptability 
表型可塑性是植物器官在复杂环境中产生一系 列不同而相对适合的表现型的潜能 (Dewitt et al. , 1998) , 是个体适应环境的方式 (Sultan ,1987)。研究 表明, 植物可以对土壤营养水平 (Wetzel \& van der Valk,1998)和枝条密度 (Idestam-Almquist \& Kautsky ， 1995)等环境变化产生可塑性响应。例如可以通过 改变根的形态 (Ryser \& Lambers, 1995 ; Fransen et $a l$. 1998)、叶子的形状和大小 ( Luther ,1983;Perez et $a l$ ，1994) 或生物量分配模式 (Turkington \& Maze， 1982 ;Idestam-Almquist \& Kautsky ,1995)等方式适应不 同的环境并充分利用环境资源 (Schlichting,1986; Greulich et al. 2001)。克隆植物由于能够对环境变 化做出快速易见的响应，因而作为研究可塑性的良 好材料而得到广泛使用( Hutchings \& de Kroon ,1994 ; 董鸣, 1996 许凯扬等,2005)。

土壤中的磷是植物生长发育的必需营养元素之 一(Marschner,1995;王庆仁等,1999)。在水生环境 条件下, 底泥中的磷通过改变根密度 (Busch et al. , 2004)、地上生物量、根冠比 (Chapin ,1980; Lorenzen et al. 2001)和生物量分配模式( Miao \& DeBusk,1999; Lorenzen et al .2001;Busch et al .,2004) 等来影响水 生植物的生长。有研究表明淡水大型植物的表型可 塑性变化更多地来自对底泥营养水平的响应而不是 对水体中营养的响应 (Xie et al, ,2005)。但是, 作 为水体中产生富营养化的一个重要因素 (Sas , 1989），磷过多也可导致水生生态系统结构与功能的 变化 (Schachtman et al . 1998; :Linkohr et al ,2002; Vojtísková et al. 2004)。

植株密度的改变对植物的表型可塑性有着重要 的影响 (Chen 2000;Cipollini \& Bergelson ,2001) ,可以 通过改变植株高度 (Nagashima et al , 1995) 、体积、 枝条生物量 (Agami \& Waisel,2002; Schroeder \& Janos ,2004)、叶片生理特征 (Cipollini \& Bergelson , 2001)和交配模式等 (Chen,2000) 来影响植株的表 型可塑性。

乌菱( Trapa bicornis) 是分布于印度、东南亚及中 国的一种扎根水生草本, 具有很强的克隆繁殖能力; 能成功地进行克隆繁殖从而占据整个水生生境 (Groth et al.,1996; Robert ,1999)。随着水体富营养 化的加剧，生物多样性丧失严重，野生状态的乌菱分 布范围也逐渐缩小, 甚至在一些湖泊中消失(简永兴 等，2001）;但作为栽培作物，在人工种植的条件下却 能在富营养化的水塘中形成高密度乌菱群落。因 此, 高密度很可能促进乌菱在富营养化水体中的适
应性。

本研究以乌菱植株为材料, 研究其对不同底泥 磷含量和植株密度的可塑性响应, 目的是检验高密 度能否提高乌菱在磷含量过高造成的富营养化环境 中的生态适应性。

\section{1 材料和方法}

\section{1 试验材料}

乌菱是菱科菱属的一年生水生草本, 茎细长, 伸 出水面的部分茎节极短, 使各叶片镶嵌展开在水面 上成盘状,称为菱盘(集宝林, 1986; Agrawal \& Mohan ,1995)。根两型, 除扎入底泥中的吸收根 (Anchoring root) 外, 尚有一种含叶绿素沉于水中的同化 根 (Green root)。吸收根具有固定植株, 有吸收营养 的功能, 而同化根除了光合作用外, 还有吸收及咜藏 养分的功能( Agrawal \& Mohan, 1995;曾宪锋和周仪， 1996)。本实验自南京郊外六合镇的菱塘采苗, 选取 茎长与菱盘大小基本一致的乌菱植株 (平均株高 $(90 \pm 10) \mathrm{cm})$ 带回温室种植。

\section{2 试验处理}

实验在南京大学浦口校区的温室中进行, 从 2005 年 5 月 17 日开始至 7 月 1 日结束。采集的菱 苗经缓苗 $3 \mathrm{~d}$ 后 种植在 $75 \mathrm{~cm} \times 50 \mathrm{~cm} \times 55 \mathrm{~cm}$ 的 塑料箱中, 箱底铺设 $15 \mathrm{~cm}$ 的底泥, 由河沙: 壤土按 重量 $1: 1$ 混合而成, 箱内储水约 $25 \mathrm{~cm}$ 。实验设置 3 个不同的底泥磷含量 (Sediment phosphorus concentration, SPC) 处理, 每个 SP 下又设置 3 个植株密度 (Plant density, PD)处理, 计 9 个处理。3 个底泥磷浓 度的处理分别为低磷 (Low sediment phosphorus concentration, LSP; 没有添加无机磷肥, 底泥总磷含量 $(27.56 \pm 0.78) \mathrm{mg} \mathrm{g}^{-1}$ ), 中磷 (Median sediment phosphorus concentration, MSP ; 添加无机磷肥, 总磷 含量 $\left.(52.85 \pm 1.30) \mathrm{mg} \mathrm{g}^{-1}\right)$, 高磷 (High sediment phosphorus concentration, HSP ; 加入 2 倍于 MSP 的无 机磷肥, 总磷含量 $\left.(115.61 \pm 2.72) \mathrm{mg} \mathrm{g}^{-1}\right)$ 。3 个 植株密度处理分别为 PD4 (每箱 4 株乌菱)、PD8 (每 箱 8 株乌菱)和 PD12(每箱 12 株乌菱)，每个塑料箱 内的植株个体均匀分布。每个处理 4 个重复。底泥 磷含量和植株密度处理的详细说明见表 1 。

\section{3 参数测定}

乌菱在各实验处理下生长 6 周后连根挖起, 带 回实验室冲洗干净, 测量主菱盘叶数、叶生物量、总 茎长与分枝数等参数。然后, 把植物样品的根、茎、 叶分开并且在 $80^{\circ} \mathrm{C}$ 的烘箱中烘至恒重, 测各部分的 
表 1 底泥磷含量和植株密度设置

Table 1 Experimental setup of sediment phosphorus concentration and plant density

\begin{tabular}{|c|c|c|c|}
\hline \multirow{2}{*}{$\begin{array}{c}\text { 植株密度 } \\
\text { Plant density (PD) }\end{array}$} & \multicolumn{3}{|c|}{ 底泥磷含量 $(\mathrm{SP})$} \\
\hline & $\begin{array}{c}\text { 低磷 SP Low SP (LSP) } \\
27.56 \pm 0.78\end{array}$ & $\begin{array}{c}\text { 中磷 SP Median SP (MSP) } \\
52.85 \pm 1.30\end{array}$ & $\begin{array}{c}\text { 高磷 SP High SP (HSP) } \\
115.61 \pm 2.72\end{array}$ \\
\hline 4 株/箱 4 individuals per container (PD4) & LSP-PD4 & MSP-PD4 & HSP-PD4 \\
\hline 8 株/箱 8 individuals per container (PD8) & LSP-PD8 & MSP-PD8 & HSP-PD8 \\
\hline 12 株/箱 12 individuals per container (PD12) & LSP-PD12 & MSP-PD12 & HSP-PD12 \\
\hline
\end{tabular}

干重。

按 Hunt (1978) 的生长分析方法计算下列参数 : 根生物量比 (Root mass ratio, RMR) = 根生物量/总 生物量 ; 茎生物量比 (Stem mass ratio, SMR) = 茎生 物量/总生物量 叶生物量比 (Leaf mass ratio ,LMR) = 叶生物量/总生物量;同化根比根长 (Special green root length ,SGRL) $=$ 同化根总长/同化根生物量, 吸 收根比根长 (Special anchoring root length, SARL) = 吸收根总长/吸收根生物量; 同化根长度比 (Green root length ratio, GRLR $)=$ 同化根总长/总生物量 吸 收根长度比 (Anchoring root length ratio,ARLR) = 吸 收根总长/总生物量;比茎长 (Special stem length, $\mathrm{SSL})=$ 茎长/茎生物量 ; 茎长度比 (Stem length ratio, $R L R)=$ 茎总长/总生物量。取烘干后的根、茎、叶 样品, 先用 $\mathrm{H}_{2} \mathrm{SO}_{4}-\mathrm{H}_{2} \mathrm{O}_{2}$ 消化, 然后使用比色法 (Xie et al. 2005) 测量同化根、吸收根、茎、叶等各器官的 磷含量 相加得到植株的总磷含量 (Total plant P concentration)。

\section{4 统计分析}

数据在 Excel 2003 和 SPSS 12.0 软件中处理。 用一般线性模型的多因素多变量方差分析 (GLM) 对 SP、PD 和二者的交互作用作初步的评估，挑选出 受 SP、PD 或二者交互作用影响显著的变量，通过一 元方差分析 ANOVA 中的 Duncan 法进一步进行多重 检验。由于同化根比根长与吸收根比根长数值偏 大, 为了保证方差齐性, 对其进行对数转换后进行统 计分析。在不同 SP 或 PD 处理下的生物量指标, 即 叶生物量、根生物量、茎生物量等, 均取以 10 为底数 的对数, 使其符合正态分布, 再用 SPSS 的线性回归 分析检验各生物量之间的异速生长关系。

\section{2 结果与分析}

2.1 底泥磷含量与植株密度对乌菱的形态及生理 生态特征的影响

通过 GLM 多因素多变量方差检验显示, SP 对
乌菱的主菱盘叶数、同化根比根长、吸收根比根长、 叶磷含量、茎磷含量、同化根磷含量、吸收根磷含量 以及总磷含量都有显著 $(p<0.05)$ 或极显著 $(p<$ 0.01 ) 影响 (数据未显示), 而对其它生长与形态参 数均无显著影响 $(p>0.05) ; \mathrm{PD}$ 则对乌菱各测量指 标均无显著影响 $(p>0.05)$ 。 $\mathrm{SP}$ 与 PD 的交互作用 加强了对叶生物量比的影响, 达到极显著水平 $(p<$ 0.01 ), 但弱化了 SP 对乌菱的主菱盘叶数、同化根比 根长、吸收根比根长及植株各器官磷含量的影响。 以上结果说明, SP 对该种的影响远高于 PD, 但这种 影响更多地显示出对植物各器官磷含量的影响, 而 $\mathrm{PD}$ 与 $\mathrm{SP}$ 的交互作用可以削弱 SP 对乌菱的显著影 响。

\section{2 乌菱生长对底泥磷含量和植株密度的响应}

在上述植物生长及形态指标中, 选取受 SP、PD 或二者的交互作用影响显著的参数，即以主菱盘叶 数、叶生物量比、同化根比根长、吸收根比根长等参 数作图 (图 1)。数据显示, MSP-PD4 处理的主菱盘 叶数显著低于 LSP-PD4 及 HSP-PD12 $(p<0.05)$ 。 MSP-PD12 处理条件下的叶生物量比显著高于 LSPPD12 与 MSP-PD4 $(p<0.05)$; 其它处理间均无显著 差异。因此, 在低磷条件下, 低密度更适合叶的生 长; 而随着 SP 的增加, 高密度条件更适合叶的生长。 HSP-PD8 处理的同化根比根长显著高于 LSP-PD8 $(p<0.05)$,HSP-PD12 处理的吸收根比根长显著高 于 LSP-PD12 $(p<0.05)$, 其它各处理下乌菱的同化 根比根长及吸收根比根长都没有显著差异 $(p>$ $0.05 ）$, 说明随着 SP 的增加，乌菱的同化根比根长及 吸收根比根长增大。

\section{3 乌菱磷含量对底泥磷含量和植株密度的响应}

HSP 处理条件下的同化根与吸收根的磷含量都 显著高于 MSP、LSP 的任何处理 $(p<0.05$, 图 2), 此 外, HSP-PD4 处理条件下的吸收根比根长显著高于 其它任何处理 $(p<0.05)$ 。茎磷含量在 HSP-PD4 处 理达到最高，此外，HSP-PD4及HSP-PD8处理显著高 

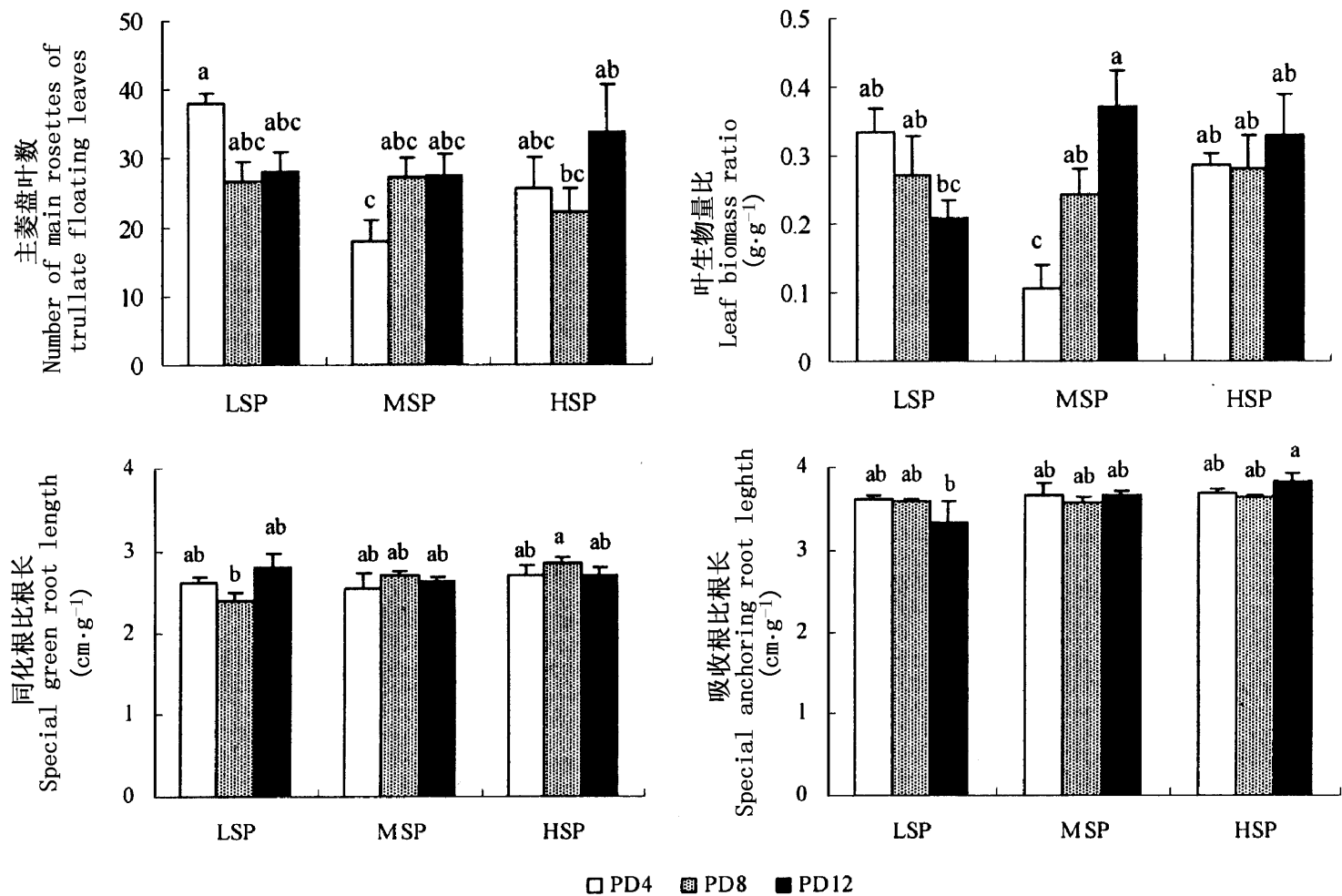

图 1 乌菱的主要生长指标对底泥磷含量与植株密度的响应

Fig. 1 The responses of the main growth variables of Trapa bicornis to sediment phosphorus concentration and plant density

平均值 \pm 标准差 Mean $\pm S E$ LSP :低底泥磷含量 Low sediment phosphorus concentration MSP :中底泥磷含量 Median sediment phosphorus concentration HSP :高底泥磷含量 High sediment phosphorus concentration PD4 每箱 4 株 4 individuals per container PD8 :每箱 8 株 8 individuals per container PD12 每箱 12 株 12 individuals per container 图中上方不同的字母表示不同处理之间通过 Duncan 法进行多重检验得出的显著性差异 Different upper letters indicate significant differences between treatments according to the results of post-hoc with Duncan test

于 LSP、MSP 处理 $(p<0.05)$; HSP-PD12 与 MSPPD12 差异不显著 $(p>0.05)$, 但与 LSP 处理及 MSP 处理下的其它密度处理具显著差异 $(p<0.05)$ 。 HSP- PD8 和 HSP-PD12 处理条件下的叶磷含量显著 高于低磷的 3 种处理以及中磷的 MSP-PD8 与 MSPPD12 处理 $(p<0.05)$ 。总磷含量随 SP 的增高而增 大 ,HSP 处理下总磷含量显著高于 LSP 及 MSP 处 理。随底泥磷浓度增高, 乌菱植株各组分磷含量及 总磷含量均呈现增高趋势, HSP 处理下植株磷含量 普遍高于 MSP 和 LSP 处理; 除了叶磷含量, 植物其 它指标均在 HSP-PD4 处理条件下达到最高。

\section{4 乌菱生物量异速生长关系分析}

在不同的 SP 和 PD 处理下, 每组处理的同化 根、吸收根、茎、叶生物量与总生物量之间的两两相 关关系呈现相似的增长趋势 (图 3)。在不同的 SP 处理下, 茎生物量与总生物量之间都呈显著线性回 归相关 $(p<0.05)$, 这就说明 SP 的变化不影响茎生 物量与总生物量之间的异速生长关系。与此相同, 在各 PD 处理下, 叶生物量、同化根生物量与总生物
量之间也都呈相似的显著线性回归相关 $(p<0.05)$ 。 然而 叶生物量与总生物量在 LSP 和 MSP 处理 下具有显著线性相关关系 $(p<0.05)$, 但在 MSP 处 理下没有显著线性相关关系 $(p>0.05)$; 同样, 同化 根生物量与总生物量在 LSP 处理下没有显著线性相 关 $(p>0.05)$ 吸收根生物量与总生物量在所有 $\mathrm{SP}$ 处理下都不呈显著线性相关 $(p>0.05)$;与此类似, PD4 处理下的茎生物量、PD12 处理下的吸收根生物 量与总生物量之间也无显著线性相关 $(p>0.05)$ 。 这表明 MSP 处理改变了叶生物量与总生物量之间 的异速生长关系, LSP 处理改变了同化根生物量与 总生物量之间的异速生长关系; 而吸收根生物量与 总生物量之间没有直线相关关系; PD4 处理改变了 茎生物量与总生物量之间的异速生长关系, 而 PD12 处理改变了吸收根生物量与总生物量之间的异速生 长关系。

\section{3 讨 论}



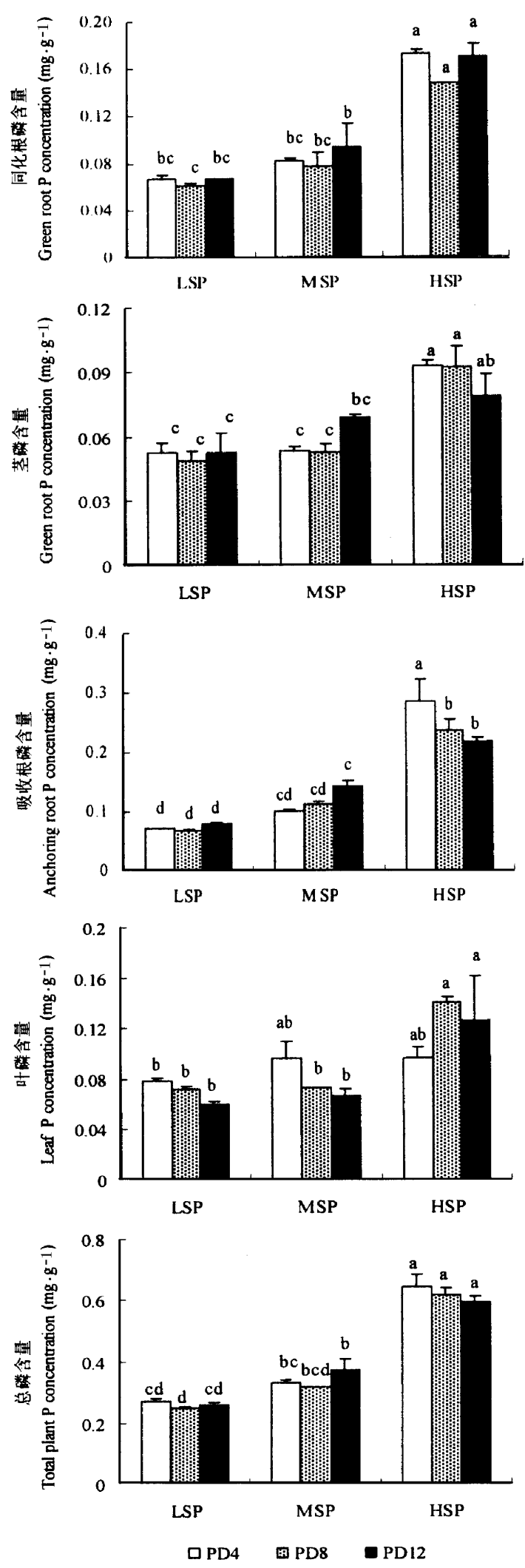

图 2 乌菱磷含量对底泥磷含量和植株密度的响应

Fig.2 The responses of plant $\mathrm{P}$ concentration of Trapa bicornis to sediment phosphorus concentration and plant density

图注见图 1 Notes see Fig. 1
2001 ;He \& Dong ,2003)。试验表明 PD 对乌菱无显 著影响，乌菱在 SP 或 PD 与 SP 两者交互作用下, 同 样产生形态、生长及生理特征的可塑性响应。SP 与 $\mathrm{PD}$ 处理甚至改变同化根、吸收根、茎、叶与总生物量 之间的异速生长关系 (图 3)。与 PD 相比 ,SP 对乌 菱生理生态特征参数的显著影响更多。

根的形态可塑性对于植物在异质性环境下获得 营养十分重要 (Fransen et al.,1998)。HSP-PD8 处 理下同化根比根长显著高于 LSP-PD8 处理 $(p<$ 0.05), HSP-PD12 处理的吸收根比根长显著高于 LSP-PD12 $(p<0.05)$,乌菱的同化根比根长、吸收根 比根长基本随着 SP 的增高而增大 (图 1)。作为根 表型指标的重要参数, 比根长的增加意味着单位重 量的根长增加。研究表明, 细长的根比粗壮的根更 有利于吸收环境中的营养元素 (Ciro et al.,1999; Rosolem et al. ,1999)，因为这大大增加了根的表面 积。所以, 随着磷浓度增高, 比根长的增加意味着乌 菱吸收磷的能力增强。本试验表明, 随 SP 的提高, 植株同化根、吸收根、茎、叶等器官的磷含量增高, 除 了叶磷含量 植物其它组分磷含量均在 HSP-PD4 时 达到最高 (图 2), 这说明乌菱通过根系形态结构和 生理生态调整对底泥磷含量产生了可塑性响应, 并 且乌菱具有富集底泥中磷的作用; 但在 SP 过量条件 下, 植株密度增高可以削弱乌菱根系富集磷的作用。

植物在不同环境条件下的资源分配格局反映了 植物发育对环境的响应规律和资源分配对策 (Geber \& Watson, 1997)。研究表明在低磷条件下, 植物的 生物量与叶面积下降 (Plesnicar et al.,1994;Kondracka \& Rychter ,1997)。叶片表面积的减少降低了 可用于光合作用的投资, 即低磷含量限制了光合作 用 (Foyer \& Spencer, 1986 ;Fredeen et al. 1990 ;Jacob \& Lawlor ,1992;Kondracka \& Rychter ,1997)。乌菱在 LSP 处理条件下, 叶生物量比、主菱盘叶数随密度增 大而减小, 说明在低磷条件下, 低密度更适宜乌菱生 长 (图 1)。而在 MSP-PD4、HSP-PD4 处理下乌菱的 主菱盘叶数及叶生物量比较低, 底泥磷含量对于乌 菱的叶片生长可能已经过量, 随着植株密度增高, 缓 解了 SP 过高的影响, 光合作用充足, 增加了可供光 合的叶片数量及分配给叶片的生物量, 高密度促进 了叶的生长。这表明乌菱通过器官生物量分配、形 态结构调整对底泥磷含量产生了可塑性响应, 而植 株密度增高可以缓解 SP 过高对乌菱叶片生长的限 制。

乌菱对底泥磷含量和植株密度产生的生长调 
叶生物量

Leaf biomas

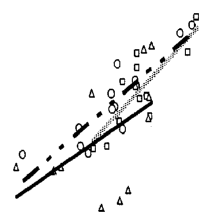

$R_{\mathrm{LSP}}^{2}=0.68 ; p_{\mathrm{LSP}}<0.001 * * *$

$R_{\text {MSP }}^{2}=0.28 ; p_{\text {MSP }}=0.076$

$R_{\mathrm{HSP}}^{2}=0.79 ; p_{\mathrm{HSP}}<0.000^{* * *}$

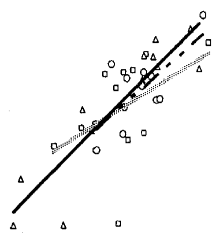

$R_{4}^{2}=0.23 ; p_{4}=0.118$

$R_{4}^{2}=0.39 ; p_{4}=0.031 *$

$R_{8}^{2}=0.74 ; p_{8}<0.000^{* * *}$

$R^{2}{ }_{12}=0.57 ; p_{12}=0.004 * *$
$R_{8}^{2}=0.83 ; p_{8}<0.000 * * *$

$R_{12}^{2}=0.55 ; p_{12}=0.006^{* *}$
同化根生物荲 Green root biomass

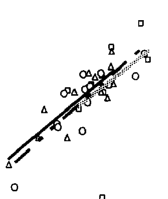

$R_{\text {LSP }}^{2}=0.20 ; p_{\text {LSP }}=0.150$

$R_{\text {MSP }}^{2}=0.74 ; p_{\mathrm{MSP}}<0.000 * * *$

$R^{2}{ }_{\text {HSP }}=0.71 ; p_{\text {HSP }}<0.000^{* * *}$

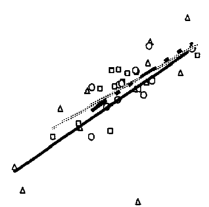

吸收根生物量 Anchoring root biomass

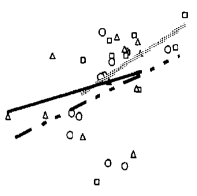

$R_{\mathrm{LSP}}^{2}=0.22 ; p_{\mathrm{LSP}}=0.142$

$R^{2}{ }_{\mathrm{MSP}}=0.11 ; p_{\mathrm{MSP}}=0.312$

$R_{\text {HSP }}^{2}=0.08 ; p_{\text {HSP }}=0.408$

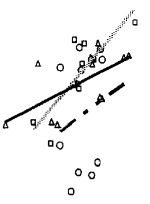

$R_{4}^{2}=0.59 ; p_{4}=0.004^{* *}$

$R_{4}^{2}=0.69 ; p_{4}=0.002 * *$

$R_{8}^{2}=0.39 ; p_{8}=0.041^{*}$

$R_{12}^{2}=0.04 ; p_{12}=0.587$

\section{图 3 乌菱生物量异速生长关系分析}

Fig.3 The mass-mass allometric relationships of Trapa bicornis

图中排在横行的变量为 $x$ 轴 纵行排列的为 $y$ 轴, 所有数据都在做相关性分析前采用以 10 为底数的对数处理。图的下方列出线性回归方 程, 随后为回归系数及相关显著性 $p, *: p<0.05 ; * *: p<0.01 ; * * *: p<0.001$ Variables listed in the row were viewed as $x$-axis, while the variables listed in column were viewed as $y$-axis. Data were logged. Linear regression formulae are shown, followed with regression coefficients and statistical significance values of $p . *: p<0.05 ; * *: p<0.01 ; * * *: p<0.001$ LSP、MSP、HSP、PD4、PD8、PD12 : 见图 1 See Fig. 1

整, 主要是通过异速生长来体现。试验表明 MSP 处 理影响叶生物量与总生物量之间的异速生长; $\mathrm{MSP}$ 处理下 植株将较少的生物量分配给叶生长所需, 进 一步证明了 MSP 处理对乌菱的叶生长产生限制。 LSP 处理影响同化根生物量与总生物量之间的异速 生长, 即在 LSP 处理下植株将较少的生物量分配给 同化根 (图 3);SP 对吸收根生长影响很大, 从图 3 可知, 分配给吸收根的生物量随 SP 增大而显著减 小, 即 $: \mathrm{LSP}>\mathrm{MSP}>\mathrm{HSP}$ 。表明在 LSP 处理下, 由 于底泥磷含量有限, 更多的生物量分配给吸收根, 而 分配给同化根的生物量较少, 因为吸收根是重要的 营养吸收器官, 而同化根除了具吸收作用外, 更重要 的是光合同化作用 (Agrawal \& Mohan,1995;曾宪锋 和周仪,1996)。PD4 处理显著改变茎生物量与总生 物量之间的异速生长, 乌菱将较少的生物量分配给 茎; 而 PD12 则改变了吸收根生物量与总生物量之 间的异速生长, 密度越高, 植株分配给吸收根的生物 量越少, 说明植株密度越高, 分配给同化根与叶的生 物量越高。表明 SP 与 PD 处理能改变同化根、吸收 根、茎、叶与总生物量之间的异速生长关系;也表明
在响应不同的环境因子时, 植物具有不同的生物可 塑性机制 (Spector \& Putz 2006)。

\section{4 结 论}

底泥磷含量对乌菱的生理生态特征产生了显著 的影响, 而植株密度处理对乌菱无显著影响。乌菱 通过调整器官生物量分配、形态结构及生理生态特 征对底泥磷含量产生可塑性响应。而底泥磷含量与 植株密度两者间的交互作用显著削弱了底泥磷含量 对乌菱生长及生理可塑性的影响，提高了乌菱在主 要由磷引起的富营养化条件下的生态适应性。

\section{参 考 文 献}

Agami M, Waisel Y (2002). Competitive relationships between two water plant species: Najas marina L. and Myriophyllum spicatum L. Hydrobiologia, 482, $197-200$.

Agrawal A, Mohan HYR (1995). In vitro germination and micropropagation of water chestnut (Trapa sp.). Aquatic Botany, 51, $135-146$.

Busch J, Mendelssohn IA, Lorenzen B, Brix H, Miao S (2004). Growth responses of the everglades wet prairie species Eleocharis 
cellulosa and Rhynchospora tracyi to water level and phosphate availability. Aquatic Botany, 78, $37-54$.

Chapin FS III (1980). The mineral nutrition of wild plants. Annual Review of Ecology and Systematics, 11, 233-260.

Chen XY (2000) . Effects of plant density and age on the mating system of Kandelia candel Druce (Rhizophoraceae), a viviparous mangrove species. Hydrobiologia, 432, 189 - 193.

Cipollini DF, Bergelson J (2001) . Plant density and nutrient availability constrain constitutive and wound-induced expression of trypsin inhibitors in Brassica napus. Journal of Chemical Ecolo$g y, 27,593-610$.

Ciro AR, Joao PTW, Silvelena V, Valdir JR (1999). The significance of root growth on cotton nutrition in an acidic low-P soil. Plant and Soil, 212, 185 - 190.

Dewitt TJ, Andrew S, David SW (1998). Costs and limits of phenotypic plasticity. Trees, 13(2), 77-81.

Dong M (董鸣) (1996). Plant clonal growth in heterogeneous habitats: risk-spreading. Acta Phytoecologica Sinica (植物生态 学报), 20,543-548. (in Chinese with English abstract)

Foyer C, Spencer C (1986). The relationship between phosphate status and photosynthesis in leaves. Planta, 167, 369-375.

Fransen BH, Kroon D, Berendse F (1998). Root morphological plasticity and nutrient acquisition of perennial grass species from habitats of different nutrient availability. Oecologia, 115, $351-$ 358 .

Fransen B, Blijjenberg J, de Kroon H (1999). Root morphological and physiological plasticity of perennial grass species and the exploitation of spatial and temporal heterogeneous nutrient patches. Plant and Soil, 211, 179 - 189.

Fredeen AL, Raab TK, Rao IM, Terry N (1990). Effects of phosphorus nutrition on photosynthesis in Glycine $\max$ (L.) Merr. Planta, 181, $399-405$.

Geber MA, Watson MA (1997). Morphological plasticity in clonal plants: the foraging concept reconsidered. Journal of Ecology, $83,143-152$.

Greulich S, Barrat-Segretain M, Bornette G (2001). Basal rosette or floating leaf canopy - an example of plasticity in a rare aquatic macrophyte. Hydrobiologia, 448, 53-59.

Groth AG, Lovett-Doust L, Lovett-Doust J (1996) . Population density and module demography in Trapa natans (Trapaceae), an annual, clonal aquatic macrophyte. American Journal of Botany, $83,1406-1415$.

He WM, Dong M (2003). Plasticity in physiology and growth of Salix matsudana in response to simulated atmospheric temperature rise in the Mu Us Sandland. Photosynthetica, 41, 297 300 .

Hunt R (1978). Plant Growth Analysis. Edwand Amold, Landon. Hutchings MJ, de Kroon H (1994). Foraging in plants: the role of morphological plasticity in resource acquisition. Advances in Ecological Research, 25, 159-238.

Idestam-Almquist J, Kautsky L (1995). Plastic responses in mor- phology of Potamogeton pectinatus L. to sediment conditions at two sites in the northern Baltic proper. Aquatic Botany, 52, 205 -216 .

Jacob J, Lawlor DW (1992). Dependence of photosynthesis of sunflower and maize leaves on phosphate supply, ribulose-1, 5-bisphosphate carboxylase/oxygenase activity, and ribulose-1, 5-bisphosphate pool size. Plant Physiology, 98, $801-807$.

Jian YX (简永兴)，Wang JB (王建波), He GQ (何国庆), Li J (李今), Chen JK (陈家宽) (2001). A comparative study of aquatic plant diversity of Haikou, Taibai and Wushan Lake in Hubei Province of China. Acta Ecologica Sinica (生态学报), 21, 1815 - 1824. (in Chinese with English abstract)

Kondracka A, Rychter AM (1997). The role of P-irecycling processes during photosynthesis in phosphated efficient bean plants. Journal of Experimental Botany, 48, 1461 - 1468.

Linkohr BI, Williamson LC, Fitter AH, Leyser HMO (2002) . Nitrate and phosphate availability and distribution have different effects on root system architecture of Arabidopsis. Plant Journal, $29,751-760$.

Lorenzen B, Brix H, Mendelssohn IA, McKee KL, Miao S (2001). Gowth, biomass allocation and nutrientuse efficiency in Cladium jamaicense and Typha domingensis as affected by phosphorus and oxygen availability. Aquatic Botony, 70, $117-133$.

Luther H (1983). On life forms, and above-ground and underground biomass of aquatic macrophytes. Acta Botanica Fennica, $123,1-23$.

Marschner H (1995). Mineral Nutrition of Higher Plants. Academic Press, London, $231-255$.

Miao SL, DeBusk WF (1999). Effects of phosphorus enrichment on structure and function of sawgrass and cattail communities in the everglades. In: Reddy KR, O' Connor GA, Schelske CL eds. Phosphorus Biogeochemistry in Subtropical Ecosystems. CRC Press, Boca Raton, 275 - 299.

Nagashima H, Terashima I, Katon S (1995) . Effects of plant density on frequency distributions of plant height in Chenopodium album stands: analysis based on continuous monitoring of heightgrowth of individual plants. Annals of Botany, 75, 173-180.

Perez M, Duarte CM, Romero J, Sand-Jensen K, Alcoverro T (1994). Growth plasticity in Cymodocea nodosa stands: the importance of nutrient supply. Aquatic Botony, 47, 249-264.

Plesnicar M, Kastori R, Petrovic N, Pankovic D (1994). Photosynthesis and chlorophyll fluorescence in sunflower (Helianthusannus L. ) leaves as affected by phosphorus nutrition. Journal of Experimental Botany, 45, 919 - 924.

Robert WP (1999). Natural enemies of Trapa spp. in Northeast Asia and Europe. Biological Control, 14, 168 - 180 .

Rosolem CA, Witacker JPT, Vanzolini S, Ramos VJ (1999). The significance of root growth on cotton nutrition in an acidic low-P soil. Plant and Soil, 212, $185-190$.

Ryser P, Lambers H (1995). Root and leaf attributes accounting for the performance of fast- and slow-growing grasses at different 
nutrient supply. Plant and Soil, 170, $251-265$.

Sas H (1989). Lake Restoration by Reduction of Nutrient Loading:

Expectations, Experiences, Extrapolations. Academia-Verlag Richarz, St. Augustin, Germany, 497.

Schachtman DP, Reid RJ, Ayling SM (1998). Phosphorus uptake by plants: from soil to cell. Plant Physiology, 116, $447-453$. Schlichting CD (1986). The evolution of phenotypic plasticity in plants. Annual Review of Ecology and Systematics, 17, 667 693.

Schroeder MS, Janos DP (2004). Phosphorus and intraspecific density alter plant responses to Arbuscular mycorrhizas. Plant and Soil, 264, $335-348$.

Spector T, Putz FE (2006). Biomechanical plasticity facilitates invasion of maritime forest in the southern USA by Brazilian pepper (Schinus terebinthifolius). Biological Invasions, 8, 255-260.

Sultan SE (1987). Evolutionary implications of phenotypic plasticity in plant. Evolutionary Biology, 21, $127-176$.

Sultan SE (2001). Phenotypic plasticity for plant development, function and life history. Trends in Plant Science, 5, 537-542.

Turkington R, Maze J (1982) . Patterns of dry-matter distribution in transplanted populations of Trifolium repens and its bearing on ecological interpretations. Canadian Journal of Botany, 60, $2014-2018$.

Vojtísková L, Munzarová E, Votrubová O, Řihová A, Jư̌icová B
(2004). Growth and biomass allocation of sweet flag (Acorus calamus L.) under different nutrient conditions. Hydrobiologia, $518,9-22$.

Wang QR (王庆仁), Li JY (李继云), Li ZS (李振声) (1999). Studies on plant nutrition of efficient utility for soil phosphorus. Acta Ecologica Sinica (生态学报), 19, 417-421. (in Chinese with English abstract)

Wetzel PR, van der Valk AG (1998). Effects of nutrient and soil moisture on competition between Carex stricta, Phalaris arundinacea and Typha latifolia. Plant Ecology, 138, 179 - 190 .

Xie YH, An SQ, Wu BF (2005). Resource allocation in the submerged plant Vallisneria natans related to sediment type, rather than water-column nutrients. Freshwater Biology, 50, 391 402 .

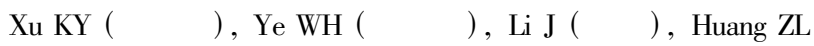
(黄忠良), Li GM (李国民) (2005). Phenotypic plasticity in response to soil water content in the invasive species Alternanthera philoxeroides. Journal of Central China Normal University (Naturalt Science Edition) (华中师范大学学报 (自然科学 版) ), 39, 100-103. (in Chinese with English abstract)

Zeng XF (曾宪锋), Zhou Y (周仪) (1996). The debate about adventitive root on the submerged stem of Trapa sp. Bulletin of Biology (生物学通报), 31(9), 28. (in Chinese) 